\title{
AN ETHNOGRAPHY STUDY ON LANGUAGE SHIFT OF MIGRANT FAMILIES
}

\author{
ENI DWI LESTARI
}

Universitas Islam Lamongan

\begin{abstract}
:
The objectives of this research are to describe the process and the factors of language shift in the migrants at Sugihwaras Village, Deket Subdistrict, Lamongan Regency. This ethnography research explores the observable and learned patterns of behavior, customs, and ways of life of a culture-sharing group. The writer emphasizes on the language shift as the part of culture. In this research, the writer presents the data by describing and analyzing the data based on the language shift as the social phenomenon and it also studied from the point of view of Sociolingustics studyThe subject of this research is two migrant families, who stay in Sugiwaras Village, Deket Subdistrict, Lamongan Regency. The first family is Madurese, and the second is Bugisnese. The research found that the process of language shift in the migrant at Sugihwaras Deket Lamongan occurs gradually. The migrant use Indonesia as their bridge to communicate with the society previously.
\end{abstract}

Keywords : language shift, migrant family

\section{Introduction}

Indonesia is multilingual country. Its residents who spread from Sabang to Merauke have different language as their mother tongue to communicate with each other. The language may has a highly important symbolic value for an ethnic group, despite the fact that few people have access to learn it and so they cannot choose to use this particular resource (Fought, 2006:241). That is true, because each region or group in Indonesia has different language. Besides, as communication tools, the role of language is a symbolic value and identity for an ethnic group.

Meanwhile, there are many people from a region who decide to migrate to another region. It is not be a matter for those migrants if they have the same

mother tongue with the target region. But, how if the migrants have different language with the society's language? While they also have their own mother tongue that is already used since long time ago. Therefore, it causes the migrants have to study the new language in order that they can adapt with the wider society.

This phenomenon happened in Sugihwaras village, Deket Subdistrict, Lamongan Regency. In this region, there are some migrants from out of East Java who decide to stay in Sugihwaras village. They are the migrants from Madura and Sulawesi. Each of them also has different language with Deket society, while Deket society uses Javanese as daily language. It causes the migrants feel difficult to communicate with the people around them if they cannot speak Javanese as dominant language. Therefore, there are factors 
motivate them to learn the language of wider society.

The phenomena whereby the process shift or displaces of one minority language mother tongue to a language of wider society in sociolinguistic study is called language shift (Holmes, 2008:56). Language shift often occurs on the migrants. There are factors which motivate the migrants to displace their mother tongue. It is as well as from themselves or demand from their environment. Those factors are economic, political, social, attitude and value. The process of language shift may require long process to make the migrants able to speak the new language fluently. But, that is all depending on each individual. Besides, the migrants also have choice to remain keeping and teaching their mother tongue to next generation as their effort to maintain their mother.

\section{Review Of Related Literature \\ Language Shift}

Language shift is the process shift or displaces of using language from mother tongue to a language of wider society which happen by the migrant society (Holmes, 2008:56). In some cases language shift occurs as a result of forced or voluntary immigration to a place where it is not possible to maintain one native language. Language undergoing shift often displays characteristic types of changes such as simpulification of complex grammatical structures. These changes are often the result of decreased use of the language in certain contexts which may lead to a loss of stylistic option (Aronoff and Miller, 2002:400).

Language shift usually occurs in bilingulism or multilingualism community because of many factors such as bilingualism, migration, economic and social factors, and also value and attitude of the language users. In the case of majority speakers, language transmission at home and at school is commonly taken from granted: at home, parents speak this language usually with the children, at school this language is usually the only or major subject and medium of instruction. In the case of minority language speakers, there is usually a mismatch between the language of the home and the language of the school. Whether parents in such a context continue to transmit their language to their children is strongly dependent on the degree to which these parents conceive of this language as a core value of cultural identity (Extra, 2007).

\section{Language Shift in the Migrant}

Migrant is usually understood to cover all cases where the decision to migrate is taken freely by the individual concerns for reason of "personal convenience" and without intervention of an external compelling factor. It applies to person and family members, moving to another country or region to better their material or social conditions and improve the prospect for themselves or their family (Perruchoud, 2004:40).

As the previously explained, the existence of the migrant provides an obvious an example of the process of languange shift. But, generelly it will most happen in the migrant who becomes minorities. Although it also may happen in the migrant who become majorities, but it has little possibility. A low economic and social status of a minority language can make it unattractive to learn and to retain through the generation, especialy when it is seen as an impediment for upward social mobility. Furthermore, without 
opportunities to participate in public life as members of a particular language minority, the right to use one's mother tongue can become meaningless, and the language may degrade to a funtional variety usable only in limited, private context (O'reilly in Brun and Wolff, 2003:5). For example, the students of East Kalimantan in Petra Christian University who study in Surabaya. Their mother tongue is Dayak language. But, when they move to study in Surabaya, they shift to use Suroboyoan language. Suroboyoan language is the language used by Surabaya's society which tends to mix between Indonesia and Javanese (not purely Indonesia). Suroboyoan language is one of the varieties Javanese that includes "ngoko" Javanese. It is not formal like standard of Indonesian. These migrant students use Suroboyoan language when talking with their freinds at campus informal situation or in daily communication with their friends who are Javanese too.

Holmes (2008:57) also states about the tendency of older generation and younger generation towards the languange. Typically the migrants are virtually monolingual in their mother tongue, their children are bilingual, and their grandchildren are often monolingual in the language of the "host" country. It means that the old generation is usually monolingual, the are able to speak with their mother tongue. Then, the second generation is bilingual, they can speak both in their mother tongue and dominants lenguage where they move and stay. Meanwhile, for the third generation, they are usually monolingual. They just can speak with the dominant language, but in case if their family cannot maintain the mother tongue.
The language shift in the migrant might possibly do not fully happen. The migrants can use both of their language, as well as the mother tongue or dominat language (Javanese) or they also can use Indonesia as lingua franca. They can use it in particular domains. As previously explanation, domain (where you are) is importants in determining which language the people will choose to use (Meyerhoff, 2006:116). Thus, the migrants can use their mother tongue in domain family at home, or religion for praying and dreaming. Meanwhile, they also can use the dominant language (Javanese) in domain of work (employment), school (education), and freindship due to their environment.

Furthermore, in learning Javanese, there is no relationship between people staying in Javanese, as well as "ngoko" and "kromo" in Javanese. Sociolinguistics have often focused more on language form than language function in charting the construction of ethnic identity. It is crucial, however, to look also at how the use of language by different groups can signal ethnic differences, because in some communities there may be few stuctural differences in the varieties used by different ethnic groups. Even when there are specific ethnically marked varieties available, particular individuals in the group may not use them, while still exhibiting an interactional style that is very different from that of someone in another group (Fought, 2006).

\section{Method}

This research is categoried as qualitative research. Qualitative research is research that includes analysis in detail and finds the meaning of the texts and interviews so that it can discover 
meaningful patterns descriptive of a particular phenomenon (Moeleong,2014:6). Meanwhile, in analyzing qualitative data book, it is defined that qualitative research is an approach to the study of the social world which seeks to describe and analyze the culture and behavior of humans and their groups from the points of view of those being studied (Bryman,2004). The coding manual for qualitative Research is intended as a reference to supplement those existing works (Saldana,2008). In this research, the writer presents the data by describing and analyzing the data based on the language shift as the social phenomenon and it also studied from the point of view of Sociolingustics study.

In most research this decision in largerly dictated by the research question and the nature of the research problem under investigation. Therefore, based on the statement, the writer determines that the area of social life is the two migrants at Sugihwaras Deket Lamongan and focuses on the language shift phenomenon, especially about the factors motivate and the process of languange shift. The subject of the data for the resarch is two migrants who stay in Sugihwaras Deket Lamongan. Those migrants have their mother tongues that are different from daily language used by society in this region (Javanese). They are a Madura's migrant with Madurese, and Sulawesi's migrant with Buginese.

\section{Findings And Analysis Subject 1}

The writer first subject is Mrs. Hanaria (38 years old). She comes from Pare-Pare, South Sulawesi. She has stayed in Sugihwaras Deket Lamongan since 2006 after married to Mr. Fauzan as the resident of Sugihwaras Village.
The mother tongue of Mrs. Hanaria is Bugis language. She was born in Parepare and stayed with her parents. Before Mrs. Hanaria migrated in Java, she also became an immigrant in Kalimantan when she was 17 years old.

She had worked in Kalimantan for eleven years. Therefore, she can speak Malay well. She met Mr. Fauzan in Kalimantan, after getting married with her husband she stayed in Sugiwaras village. She has began learning Javanese since staying in Sugiwaras village. She learned from her husband's family speaking with one another. But she still cannot speak Javanese fluently. She understood when she listened the people to speak with Javanese, although a little.

After married to Mr Fauzan, Mrs Hanaria stays with her husband in Sugihwaras village and make grocery store, then her husband work as a driver. Before Mrs Hanaria can speak Javanese, she used Indonesia to communicate with the people around her. But day by day, she can understand when she listens to the people speaking with Javanese and right now she can speak Javanese, not very well though.

According to Mrs Hanaria, learning Javanese is not easy. At first time when she listened to the people speaking Javanese, she could understand the aim of the topic speaking, but to imitate and repeat it again she got difficulty.

Mrs Hanaria stated that she learns Javanese by listening to the people who are speaking with one another. She can hear Javanese everywhere because the people around her certainly use it, such as at home, she can listen to Javanese when her husband. Besides she also concerns when the seller and buyers communicate in the market. Mrs Hanaria learns Javanese 
not only word by word, but also in a sentence repeat it. If there any words which are not understood. She shares and asks her husband family,s.

Mr. Fauzan, her husband, never teaches Javanese to Mrs. Hanaria directly. Even, they sometimes use Indonesia for communication. Mrs. Hanaria still feels difficult to understand, especially when her husband speaks quickly. They usually use Javanese for daily conversation. For this time, Mrs. Hanaria still can speak Javanese with "ngoko" Javanese and little in "kromo" Javanese, but not as well as "ngoko" Javanese because she more frequently hears the people in the market using "ngoko" Javanese to speak each other in informal situation or when her customer.

Meanwhile, for "kromo" Javanese, she learns from her husband. If in "ngoko" Javanese, she can learn through sentence by sentence, but for "kromo" language, her husband teaches through word by word, and shows the meaning of it, because she seldom hears the people speak with "kromo" Javanese. There are words in Buginese which are the same as Javanese. For example, "sampean, panjenengan". So,for the simple words, Mrs. Hanaria understands it. Then, for familiar sentence, such as "njenengan tiang pundi?" she can understand it. Formerly, many people who asked it and her husband explained the meaning of it. Actually, in Javanese there are the degree of language. They are "ngoko", "kromo", and "kromo inggil". But, mostly the people unite between "kromo" and "kromo inggil" as "kromo" Javanese.

In using language, Mrs. Hanaria adapts with who she is to speaking. She uses Javanese to communicate with her husband, neighbors, customers. But also still uses Bugis to communicate with her family from Sulawesi. To communicate with her husband she uses Javanese and Malay depending on situation and condition.

Mrs. Hanaria says that she likes Javanese, because it is polite. In other hand, for her, economic factor is the main factor to learn Javanese. It is because her customers and community in the market certainly using Javanese. Therefore, she can be closer to them and has many customers. Besides, all people around her also communicate using Javanese.Therefore, Mrs. Hanaria must learn Javanese to adapt herself with the environment.

\section{Data Presentation Based on Observation \\ Subject 1}

Mrs. Hanaria came from Pare-pare, South Sulawesi. She has stayed in Sugihwaras Village since 2006. The location of her house is in border of highway, she had a grocery store in front of her house. The writer just communicates first time with Mrs. Hanaria when doing interview. When the interview was going on, she often spoke Indonesian more to answer the writer's question early, though the writer gave question's by Javanesse. But sometimes, she used both of Javanese and Indonesia.

In a moment, the writer first came to Mrs. Hanaria house, Mr. Fauzan explained the writer's aim to Mrs. Hanaria by Buginese. They did it may because they did not want the writer know that they said. Before, the writer only asked permission to Mr. Fauzan, while in that time, Mrs. Hanaria went to market. They might use Malay as code when they did not want the others people know what they 
talk about. By doing that, they could hide their conversation and the people around them not understand.

\section{Subject 2}

Mr. Abdul Wahid came from Sampang, Madura. $\mathrm{He}$ has stayed in Sugihwaras Village since 2000. The location Mr. Wahid house is in a narrow alley. There are just two house which as row as his house. It is behind of other house, so the people cannot see his house if they do not enter the alley because his house is covered by other house in front of it.

According Mrs. Siti, Mr. Wahid's neighbor, They seldom interacts with the people around her. Mrs. Siti also says that Mr. Wahid house always closed. The family would open door if there are the people who knock it. Mr. Wahid work in Karangbinangun Military Headquarters (Koramil). He goes to office every day, except on Saturday and Sunday. He works at 08.00 a.m and go home 05.00 p.m. Mostly, he spent his time in office. So, he seldom associates with their neighbor in day time, but in Saturday and Sunday he stays at home. According to Mrs. Maryana, his husband has many friends in Sugihwaras Village. Formerly, if Saturday or Sunday, he seldom sleeps in his boarding. He often sleeps in his friends home and plays with them more.

Beside when there is guest in his home $\mathrm{Mr}$. Wahid adapts the language of those guests. Mostly, the people knew that Mr. Wahid is not Javanese, therefore the guest usually uses Indonesia, but there also the use of Javanese.

\section{Data Analysis}

\section{The process of Language Shift}

Language shift is the one of phenomena in society life. Especially for the migrants who move to others region which have different mother tongue. They are as though get demand to shift to the language of wider society with any reasons. It is because the migrant live together and must adapt the language society, especially if they are the migrant minorities. There is process to create willingness, to learn new language through any ways, to accustom, and finally to use it in daily communication.

Furthermore, the process of language shift can be presented in some points. First, the language shift occurs through gradual process. It needs the process whereby the migrants over time can adopt the new language of the wider society's mother tongue then apply it in their daily life when they communicate with the wider society. The process of language shift can showed by the willingness of migrants to learn new language, then learn it little by little therefore finally the migrants have capability to communicate using the language of wider society and this process accours gradually. Based on the result interview and observation subject's, the writer can be divid the process language shift in some parts as follows:

\section{* The role of lingua franca}

Lingua franca uses as common means of communication among people whose native languages are mutually unintelligible (Meyerhoff, 2006:292). Based on the previous explanation, Indonesia is Lingua Franca as the bridge to correlate between the migrants and the wider society to create a good communication. This case also was done by the writer's subject as the part of language shift process. For example : 
Question : Dulu sebelum bisa bahasa Jawa sampean pake' bahasa apa? (When you still cannot speak Javanes before, what language do you use first?)

Subjek 1: Pakai bahasa Indonesia (I use Indonesian language).

Indonesia is national language. That is why the people use it as lingua franca because mostly the people understand it. Occasionally the people would be stiff to use it if they seldom use it for daily communication previously. Actually the migrants can use Indonesia to communicate with the people arround. But they feel uncomfortable, so they want to learn Javanese. The language shift accours gradually with their capability to master Javanese as their new language. So, Indonesian has the function as lingua franca to connect communication between the migrants and local residents before they can speak Javanese.

\section{* The difficulty level}

The capability of each individual to master the words in Javanese is different. It depends on each of individual. There is migrants who considers that Javanese is difficult, and the other is easy. For example :

Question : Kalau menurut sampean bahasa Jawa itu mudah ta susah? (in your opinion, is Javanese easy or difficult?)

Subject 1 : Susah mbak. Bisa dengernya, gak bisa ngomongnya. (it is difficult Miss. I can listen it, but not for speaking it )

Based on the statements above, there is the difficulty level which differents between those subject and their reason. Subject 1 is difficult, meanwhile subject 2 is not. It means speed of language shift is also influenced by the length subject understand Javanese. So, the language shift can be occurred rapidly or slowly.

\section{* Time necessity}

The difficulty level influences the time which the subjects' need to learn Javanese. If the subject is difficult, it means the subjects need time to learn Javanese. Therefore, the speed of language shift is also doing slowly. But, it depends on each of individuals. For Example :

Question: Sampean belajar bahasa Jawa kira- kira berapa lama?

(How long do you learn Javanese)

Subject 1 : Ya gak bisa ditentukan mbak, soalnya kan lihat dari orang-orang, gak bisa ya tanya. (It cannot determine. It is because I pay attention from the people. If I do not understand, I ask).

The time necessary of subjects cannot be determined. It is the process of language shift gradually. They do not know all Javanese words, and maybe the subjects can find new words every day.

\section{* The way to learn new language}

As explanation above, language shift occurs gradually. In the beginning, when the migrants feel have willingness to learn new language, next they would to learn those new language through any ways. For example:

Question : Bagaimana caranya sampean belajar bahasa Jawa?

(How do you learn Javanese?)

Subject 1: Saya itu belajar mendengarkan orang, terus tanya suami. Suami saya itu kan asli orang jawa

(I learn by listening the people say, and then ask to my husband. Because my husband is native Javanese). 
There are many ways for the migrants to learn Javanese. Such as the statements above, the first subject learns Javanese by listening what the people says in the market, her grocery store and asks to her husband who is able to speak Javanese too. Meanwhile, the second subject learn Javanese by associating with the people around who is native Javanese.

Besides, there are two styles of Javanese. They are "ngoko" Javanese and "kromo" Javanese. Each of styles has different words and different time of using. "ngoko" Javanese is more often used, because it is used for daily. Communication in informal situation. Meanwhile, "kromo" Javanese is used for formal situation. As the statement above, subjects get difficulty when they learn "kromo" javanese, it is because they seldom listen the people use it. Meanwhile, for "ngoko" Javanese, the subject can understand it quicker than "kromo" Javanese because it is often used for daily communication.

\section{* The length of stay}

The length of stay might influence the process of language shift. In fact, when the migrants have stayed in new region for long time, they have capability to speak with new language. Although, the speed of the process language shift cannot be determined through it is because capability for each individual to accept and understand new language is different. Subject 1 just recently stays in Sugihwaras Village, but she already able to speak Javanese, such as at home. Whereas, the subject 2 has stayed since 2000 therefore he has been able to speak Javanese fluently actually.

Second, it is neeed to know that the process of language shift can be determined of the domain. Domain is the social and physical setting in which speaker find themselves. The domain (where you are) is important in determining which language the people will choose to use (Meyerhoff, 2006: 116). For example:

The domain affects the process of language shift. More often the migrants use the new language, it means that the process of language shift occurs rapidly more. Thus, when the migrants still often use their mother tongue, it means that the process of language shift occurs slowly. It is because the migrants still have opportunity to use their mother tongue. Based on the statements above, the subjects more often use Javanese than their mother tongue, because the people around them are Javanese. But, the subjects also still have moment whereby they can maintain their mother tongue.

Third, language shift occurs through intergeneration. Almost all the shift language cases occur through intergeneration. Involve more than one generation (Sumarsono, 1993). It occurs when the migrants have already experienced language shift to the language of wider society as dominant language. The migrants as second generation can be bilingual, between the new language and mother tongue. Meanwhile, the parents of migrant as first generation are monolingual, only speak in mother tongue. In other hand, the children as the third generation might be monolingual too, because they only can speak with the new language as the result of language shift from their parents. But most often in such families, parents use the majority language to their children. For example :

Subject 1 : Sekarag wes iso' bahasa Jawa, Kalau anak juga pakai Bahasa Jawa, 
karena Bahasa Bugis blom bisa. (I can speak Javanese right now. For my daughter understand Javanese, he has not understood Buginese yet).

Regarding those statement, for subject 1 , first generation is monolingual, mother tongue, second generation is bilingual Javanese and Buginese, and then the daughter as third generation is monolingual Javanese. Next, for subject 2, the language shift occurs in beginning from first generation, because his family in Java, so he can speak Javanese, whereas the subject as second generation also does and for the next generation will see the place of live.

\section{The Factors Motivate Language Shift}

Language shift occurs because there are factors motivate it. According to Holmes (2008:65-69), there are some factors contributing to language shift, they are economic and political factors, social factors, demographic factors, and attitudes and value. Those factors can be the reason why the migrants shift learn new language as the wider society's language.Then, the explanation of those factors can be presented as follows :

\section{Economic and political factors}

Economic factors becomes one of the reason why the migrants have to learn new language, in this case is Javanese. This is concerns with their necessary carries out their jobs. Therefore, in order that their job is going fluently, they have to adopt the language of wider society.

\section{Social Factors}

The migrant usually have no reason to take active steps to maintain their mother tongue. But, there are some moments and domains where by the migrants can remain use their mother tongue, although they not often like the domaint language more. Man is social creature. They always interact with the people around. Therefore they have to follow the dominant language of wider society. So, the environment can give influence in shift language.

\section{Demographic factor}

Demographic factor is also relevant for the speed of language shift. Resistance to langauge shift tends to last longer in rural than in urban areas. Whereas, all people Sugihwaras Village uses Javanese. Therefore the migrant who move in Sugihwaras adapt Javanese in order that they can interact and communicate with the wider society. So, the language shift in urban area such as in Sugihwaras motivates language shift.

\section{Attitudes and value}

The value of a language influnce shift language. Language is the symbol of an ethnic. Shift language can be occured rapidly when the people in a group or ethnic is not pround again toward their language. Even if there is opinion and consideration that the new language has the high value. Although it does not happen in this case. But, in this research, the writer finds that there is good opinion toward Javanese and that is the reason why the subject learns Javanese.

A good of Javanese causes the people are interesed and happy to learn it. It means the migrants consider that Javanese has high value. Additionally that school institution can be the factor motivates language shift. In this case, school becomes a domain whereby the children of migrants learn Javanese because they get influence 
from their friends in the school. Moreover, generally the teachers use both of Javanese and Indonesia for teaching learning process in the class

\section{Conclusion}

The process of language shift in the migrant at Sugihwaras Deket Lamongan occurs gradually. The migrant use Indonesia as their bridge to communicate with the society previously. Besides, there are some points which influence the process of language shift, such as the degree of difficulty, time necessity, the way to learn new language, and the length of stay. While, domain (where they are) determines how is the process of their language shift occurs through intergeneration.
Gabrielle Hogan-Brun and Wolff Stefan. 2003. Minority Language in Europe.

New York: Palgrave Macmillan.

Hancock R. Dawson and Algozzine Bob. 2006. Doing Case Study Research. New York. Teachers College Press.

Holmes, Janet. 2008. An Introduction to Sociolinguistics, Third Edition. London: Pearson ESL.

Krippendorff, H. Klaus. 2003. Content Analysis An Introduction to Its Methodology. London: SAGE Publication ltd.

Lexy J. Moleong. 2014. Metodologi Penelitian Kualitatif. Bandung: Remaja Rosdakarya.

Perruchoud, Richard. 2004. Glossary on Migration. International

Organization for Migration.

Saldana, Johnny. 2008. The Coding

Manual for Qualitative Researchers. London: SAGE Publications ltd

\section{References}

Aronoff and Miller. 2002. The Handbook of Sociolinguistics. Blackwell Reference Online.

Berg L. Burch. 2004. Qualitative Research Methods for Social Science. Boston: A Pearson Education Company.

Bryman, Alan. 2004. Analyzing Qualitative Data. London: Routledge.

Extra Guus. 2007. Dealing with New Multilingualism in Europe. Monash University Epress, 30 (2) : 181.

Fought, Carmen. 2006. Language and Ethnicity. New York: Cambridge University Press. 